Vol. 18 (2009): 45-56.

\title{
Metal concentrations in oats (Avena sativa L.) grown on acid sulphate soils
}

\author{
Rasmus Fältmarsch ${ }^{1 *}$, Peter Österholm ${ }^{1}$, Maria Greger ${ }^{2}$ and Mats Åström ${ }^{3}$ \\ ${ }^{1}$ Åbo Akademi University, Department of Geology and Mineralogy, FI-20500 Åbo, Finland \\ ${ }^{2}$ Department of Botany, Stockholm University, SE-10691, Stockholm, Sweden \\ ${ }^{3}$ Department of Biology and Environmental Science, Kalmar University, SE-39182 Kalmar, Sweden \\ *email: rasmus.faltmarsch@abo.fi
}

\begin{abstract}
The aim of the study was to investigate the impact of soil chemistry on the concentrations of Co, Ni, $\mathrm{Zn}$, $\mathrm{Mn}, \mathrm{Cu}$ and $\mathrm{Fe}$ in oats (Avena sativa $\mathrm{L}$. cv. Fiia) grown on Finnish acid sulphate (AS) soils with varying geochemical characteristics. Twenty two soil profiles, which were sampled to a depth of $1 \mathrm{~m}$ (five $20 \mathrm{~cm}$ section splits), and 26 composite oat grain samples were collected on a total of five fields. The concentrations of $\mathrm{Co}, \mathrm{Ni}, \mathrm{Zn}$ and $\mathrm{Mn}$ in the grains were correlated with the $\mathrm{NH}_{4} \mathrm{Ac}$-EDTA-extractable concentrations in the soils. However, as these four chalcophilic metals are in general easily lost to drains and not retained as a large pool in the soil in easily-extractable form, also the concentrations in the oats were not in general elevated as compared with average values on other soils. On one of the fields, however, the Co and Ni concentrations in the soil, and thus also in the oats, were clearly elevated. Copper and Fe displayed no correlation between the soil and oat concentrations, indicating that the plant-uptake mechanisms are much more important than variations in geochemistry. It was suggested that the $\mathrm{NH}_{4} \mathrm{Ac}-\mathrm{EDTA}$ solution was not efficient in extracting $\mathrm{Fe}$ and $\mathrm{Cu}$, which shows that these metals are bound in relatively immobile oxyhydroxides.
\end{abstract}

Key-words: acid sulphate soils, oats, metals, $\mathrm{NH}_{4} \mathrm{Ac}$-EDTA, (bio)geochemistry

\section{Introduction}

A total of approximately 17-24 million ha acid sulphate (AS) soils are found around the world, with the most significant occurrences in Africa, eastern Australia, Asia and Latin America (Ritsemaa et al. 2000, Andriesse and van Mensvoort 2002). In a global perspective, the primary cause for the development of these soils is oxidation of sulphide-bearing sediments due to lowering of the groundwater table. The oxidation process can be a 
Fältmarsch, R. et al. Metal concentrations in oats grown on acid sulphate soils

result of natural isostatic land uplift and/or artificial drainage (mostly on farmland), which lowers the groundwater table and consequently exposes the sediments to atmospheric oxygen. An endproduct of the oxidation process is sulphuric acid, giving rise to very acidic conditions ( $\mathrm{pH}$ between 2.5 and 4.5 ), which in turn mobilises large fractions of metals in the soils from both dissolving metal sulphides (Golez and Kyuma 1997) and other minerals, such as metal-bearing aluminosilicates (Palko 1994). The acidic and metal-rich runoff from these soils affect adjacent surface waters and as a consequence, spatially and temporally variable impacts on aquatic life (e.g. fish kills) are common (Callinan et al. 1993, Fältmarsch et al. 2008).

In Europe, the largest AS soil occurrences are found in Finland (1600-3000 km²) (Palko 1994, Yli-Halla et al. 1999, Andriesse and van Mensvoort 2002) and Sweden (500-1400 km²) (Öborn 1994, Andriesse and van Mensvoort 2002). The majority of the Finnish AS soils are found on coastal lowlands in the mid-western parts of the country. These soils have developed mainly on fine-grained sulphide-bearing sediments deposited during the Holocene in the brackish Baltic Sea. Distinguishing features are e.g., a high sulphate concentration, low $\mathrm{pH}$ and volume weight and a high pore volume (Wiklander and Hallgren 1949, Palko 1994). These soils are often very productive farmlands due to their favourable structure after drainage. The development and maintenance of the soil structure is facilitated by the relatively high content of organic matter and significant development of ironand aluminium precipitates along aggregate-/crack walls. However, intensification of drainage practises, especially the utilisation of modern subsurface drainage techniques, significantly increases the oxidation and thus the mobility of metals and acidity in these soils (Erviö and Palko 1984, Palko and Yli-Halla 1988, 1990, Palko 1994, Öborn 1994, Dent and Pons 1995, Österholm and Åström 2002, Joukainen and Yli-Halla 2003, Sohlenius and Öborn 2004, Österholm 2005). Therefore, efficient topsoil liming of reclaimed AS soils is required to counteract the acidity produced by sulphide oxidation. The disturbance of AS soils is of public concern, primarily because of the frequent massive fish kills related to the "lethal" waters originating from these soils (Hildén et al. 1982, Hudd et al. 1984). While it is known that huge amounts of acidity and potentially toxic metals are leached from the Finnish AS soils resulting in serious damage on aquatic biota (Meriläinen 1989, Vuori 1996), little is known about the metal uptake in cereals grown on these soils. Only one study, to our knowledge, has been conducted, and it revealed significantly elevated concentrations in oat grains of $\mathrm{Mn}$ (oats grown on AS soils: $136 \mathrm{mg} \mathrm{kg}^{-1}$; Finnish average values: $\left.72 \mathrm{mg} \mathrm{kg}^{-1}\right)$, Co $\left(0.50 / 0.08 \mathrm{mg} \mathrm{kg}^{-1}\right), \mathrm{Ni}$ $\left(6.4 / 2.8 \mathrm{mg} \mathrm{kg}^{-1}\right)$ and $\mathrm{Fe}\left(142 / 60 \mathrm{mg} \mathrm{kg}^{-1}\right)$ (Varo et al. 1980, Yli-Halla and Palko 1987).

The aim of the study was to assess the role of soil chemistry on metal concentrations in oats (Avena sativa L. cv. Fiia) grown on Finnish AS soils with varying geochemical characteristics.

\section{Material and methods}

\section{Study area}

Five cultivated fields (F1-F5) located on AS soils on the coastal plains of mid-western Finland (Ostrobothnia) were selected for this study. The fields, which are located within $63.0^{\circ} \mathrm{N}$ to $63.16^{\circ} \mathrm{N}$ and $21.6^{\circ} \mathrm{E}$ to $22.15^{\circ} \mathrm{E}$, have a low relief and are situated close to the present sea level. Cultivated fields located in this region require, in order to maintain an aerated rooting zone, efficient drainage management by which rain and snow melt water are rapidly discharged and the ground water table kept well below the ground surface. A negative side effect is that the oxidation of the inherent iron-sulphides increases, which significantly lowers the $\mathrm{pH}$ and consequently mobilises potentially toxic metals in the soil. The soil type that develops is an AS soil.

Field 1 (F1) is an experimental field previously used for monitoring of e.g. hydrochemistry of runoff from AS soils and which is described in detail by Bärlund et al. (2004). Plots Nr. 17 and 20 were selected, each representing an area of 0.07 ha (720 $\mathrm{m}^{2}$ ). The other four fields (F2-F5) were between 1.2 
Vol. 18 (2009): 45-56.

and 2.5 ha in size and located on typical Finnish AS soil arable land. The main three characteristics for all five soils were: (1) yellow to reddish precipitates at soil depths of 30-90 cm caused by $\mathrm{Fe}(\mathrm{III})$ phases, (2) no distinct topsoil layer, and (3), fine-grained material (mainly silt and clay) extending from 20-40 cm downwards in F1-F4 and from $50-60 \mathrm{~cm}$ at F5. The latter site was, due to a coarser grain size in the upper part, clearly dryer than the others.

The mean annual temperature is approximately $+3{ }^{\circ} \mathrm{C}$, with July and August as the warmest months $\left(+15^{\circ} \mathrm{C}\right)$ and December to March the coldest (below $0{ }^{\circ} \mathrm{C}$ ). The mean annual precipitation is approximately $500 \mathrm{~mm}$ (Atlas of Finland 1987). The summer of 2006, when sampling took place, was the hottest and driest in a century. Metamorphic granitoids, carbonate-poor mica gneisses and metasedimentary rocks (e.g. mica schists) are the primary bedrock types in this area (Korsman et al. 1997). The area is, overall, dominated by glacial till derived from local bedrock, but agricultural fields like the ones selected for this study are found on Holocene (often sulphide-bearing) sediments which often have developed into AS soils. The quantity of anthropogenic pollution is low, since no big industries are located close to the study area. Agriculture is common in these rural parts of midwestern Finland, where approximately $50 \%$ of all the AS soils in the country are located (Fig. 1).

\section{Sampling, sample preparation and chemical analysis}

Five soil profiles were sampled in an uniform pattern in F2-F5 with an auger to a depth of $1 \mathrm{~m}$, while only two soil profiles were collected in F1 due to its small size. The 22 profiles collected were subdivided into five vertical splits, each representing a $20 \mathrm{~cm}$ section. These 110 subsamples were sealed in plastic bags and $\mathrm{pH}$ was subsequently determined in the laboratory with a Mettler Toledo inlab 426® sediment electrode, which was inserted in the soil. Deionised water was added to each subsample to assure contact with the electrode and the soil (Puustinen et al. 1994). Grains from oat (Avena sativa L. cv. Fiia) were collected from the same sites. Six

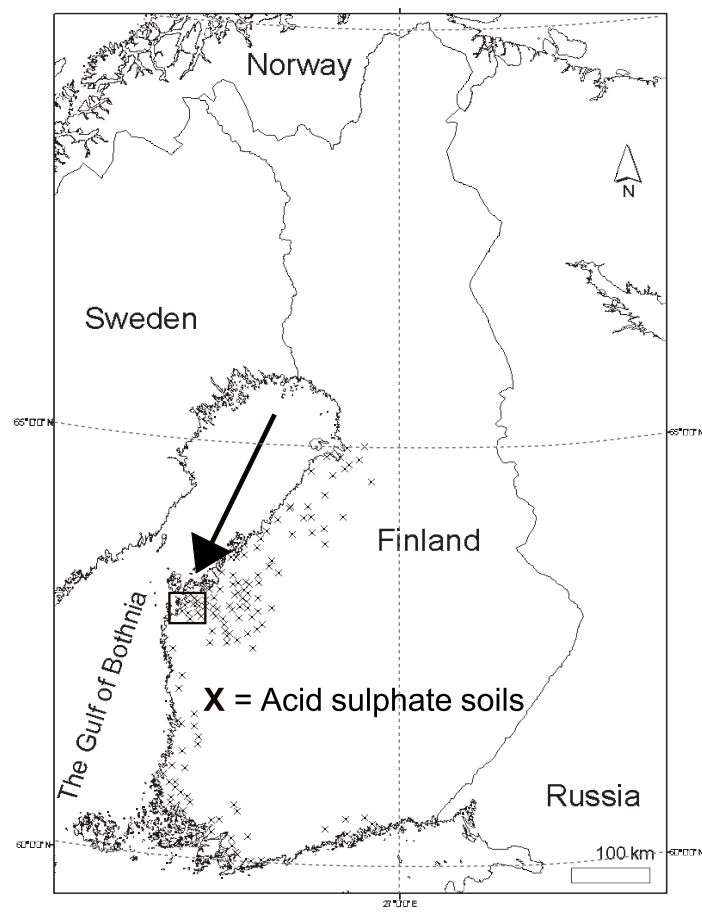

Fig. 1. Distribution of acid sulphate soils in Finland (Palko 1994) and location of the study area in mid-western Finland.

samples from F1 (three samples from each of plot nr. 17 and 20) and five from each of the other fields (F2-F5), giving a total of 26 oat samples. Each oat sample was collected from all cardinal points within a radius of approximately $0.5 \mathrm{~m}$ from the centre of the corresponding soil sampling point. An approximately $300 \mathrm{~g}$ oat sample was collected by hand using vinyl gloves.

The soil samples were dried at $40{ }^{\circ} \mathrm{C}$ for 5 days and subsequently milled in a quartz mortar to a fine powder. The oat samples were stored in plastic bags in a freezer at $-18{ }^{\circ} \mathrm{C}$ and dried at $60{ }^{\circ} \mathrm{C}$ for 72 hours before pretreatment. The oat samples, consisting of leaflets and grains, were separated with an aspirator at MTT Agrifood Research Finland in Jokioinen. The grains were sorted with a $2 \mathrm{~mm}$ sieve, thus obtaining an uniform grain size sample, and subsequently weighed. The oat grains were milled in a quartz mortar by hand. 
Fältmarsch, R. et al. Metal concentrations in oats grown on acid sulphate soils

The soil samples $(1.0 \mathrm{~g})$ were digested in $10 \mathrm{~mL}$ acid ammonium acetate-EDTA ( $0.5 \mathrm{~N}$ ammonium acetate $0.5 \mathrm{~N}$ acetic acid $0.02 \mathrm{M}$ EDTA, below referred to as $\mathrm{NH}_{4}$ Ac-EDTA) solution at $\mathrm{pH} 4.65$, rolled for 1 hour and subsequently analysed for $\mathrm{Co}, \mathrm{Cu}, \mathrm{Fe}, \mathrm{Mn}, \mathrm{Ni}$ and $\mathrm{Zn}$ by ICP-ES/MS. The purpose of this extraction method was to target ions adsorbed by soil minerals and co-precipitated with carbonates, thus simulating the easily available (bioavailable) fraction in the acid soil. A $0.5 \mathrm{~g}$ portion of the soil profiles $40-60 \mathrm{~cm}$ split $(\mathrm{n}=22)$ was analysed for the above mentioned elements plus $\mathrm{S}$ by ICP-MS after partial digestion in $3 \mathrm{~mL} 2: 2: 2$ $\mathrm{HCl}: \mathrm{HNO}_{3}: \mathrm{H}_{2} \mathrm{O}$ (aqua-regia extraction) at $95{ }^{\circ} \mathrm{C}$ for 1 hour. The aqua-regia digestion dissolves phyllosilicates, organic material and metal sulphides, however, the most weathering resistant minerals, e.g. quartz, feldspars and crystalline oxides, are poorly dissolved (Räisänen et al. 1992).

A separate $1.0 \mathrm{~g}$ portion of the oat samples ( $\mathrm{n}=26)$ was digested with $2 \mathrm{~mL} \mathrm{HNO}_{3}$ for 1 hour following a $6 \mathrm{~mL}$ digestion in $3 \mathrm{~mL} 2: 2: 2$ $\mathrm{HCl}: \mathrm{HNO}_{3}: \mathrm{H}_{2} \mathrm{O}\left(\mathrm{HNO}_{3}+\right.$ aqua-regia $)$ at $95{ }^{\circ} \mathrm{C}$ for 1 hour and analysed by ICP-MS for $\mathrm{Co}, \mathrm{Cu}, \mathrm{Fe}$, $\mathrm{Mn}, \mathrm{Ni}$ and $\mathrm{Zn}$. The $\mathrm{HNO}_{3}$ + aqua-regia digestion extracts near-total element concentrations bound in the oats, however, some elements may precipitate on the fibrous residue in the digestion.

Ten and four randomly selected replicates for the $\mathrm{NH}_{4}$ Ac-EDTA and $\mathrm{HNO}_{3}+$ aqua-regia extraction, respectively, were analysed for the determination of analytical reliability. Based on the coefficient of variation by Gill (1997) the $\mathrm{NH}_{4} \mathrm{Ac}$-EDTA and $\mathrm{HNO}_{3}$ + aqua-regia extraction was for $\mathrm{Co}, \mathrm{Cu}$, $\mathrm{Fe}, \mathrm{Mn}, \mathrm{Ni}$ and $\mathrm{Zn}$ better than $9 \%$ and $7 \%$, respectively (except the $\mathrm{HNO}_{3}+$ aqua-regia-extractable Fe which was $16 \%$ ).

\section{Reference data}

In 1974 a total of 2015 topsoil samples $(0-20 \mathrm{~cm})$ were collected from cultivated soils throughout the country (Sippola and Tares 1978), and in 1972-1976 a total of 36 oat samples were collected from 10 national granary stores and five commercial mills (Varo et al. 1980). These stores and mills were the most important grain production areas in the country and thus represented the vast bulk of cereal grains for Finnish consumption. The aim of the studies by Sippola and Tares (1978) and Varo et al. (1980) was to gather data on the element concentration of cultivated topsoils and crops grown on these soils throughout Finland. While it is possible that AS soils and oats grown on these type of soils might be included in the reference data sets, their effect on the concentration levels will be of minor importance since the reference samples represent the whole of Finland (relatively small proportion of AS soils). The oat grain samples were analysed by AAS after dry ashing for 40 hours at $500{ }^{\circ} \mathrm{C}$ following digestion in $\mathrm{HCl}-\mathrm{HClO}_{4}-(\mathrm{Cu}, \mathrm{Fe}, \mathrm{Mn}$ and $\mathrm{Zn}$ ) and $\mathrm{HNO}_{3}-\mathrm{HClO}_{4}(\mathrm{Co}, \mathrm{Ni})$ solution (Saari and Paaso 1980). The soil samples $(n=2015)$ were analysed for $\mathrm{Co}, \mathrm{Cu}, \mathrm{Fe}, \mathrm{Mn}, \mathrm{Ni}$ and $\mathrm{Zn}$ by AAS after $\mathrm{NH}_{4}$ Ac-EDTA-extraction (0.5 N ammonium acetate $0.5 \mathrm{~N}$ acetic acid $0.02 \mathrm{M}$ EDTA at $\mathrm{pH} 4.65$ ) for 1 hour with a volume ratio of soil/extractant of 1:10 (Lakanen and Erviö 1971, Sippola and Tares 1978). The mean values of elements in those studies are used as a reference and termed Finnish average values (FAV) in our study.

The same soil extraction method $\left(\mathrm{NH}_{4}\right.$ Ac-EDTA) was used in the FAV- and present study to simulate the easily available concentrations of metals and hence, a comparison between results should be fairly applicable. However, direct comparisons of multielement datasets, which vary in regard to sampling methods and/or analytical techniques, time period between studies and inter-laboratory differences, should be done with utmost discretion and without attention on fine details. In the present study the comparison with the FAV is only considered to serve as a rough indicator of background values. Although the pre-treatment and extraction methods used for the analysis of the chemical composition of oats in the FAV study differed compared with the present one, both methods are designed to provide near total concentrations bound in oats. The FAV data can thus be used for comparison, as others have done before (e.g. Erviö and Palko 1984, YliHalla and Palko 1987, Palko and Yli-Halla 1988), however, keeping in mind possible inter-dataset differences and that the material only is used as a 
Vol. 18 (2009): 45-56.

rough indicator of background concentrations in Finnish oat grains.

\section{Results and Discussion}

\section{General geochemistry}

The $\mathrm{pH}$ decreased down the soil profile in all fields (Fig. 2). The higher $\mathrm{pH}$ towards the surface, which is a result of heavy topsoil liming and a rather high organic matter concentration (indicated by the typical brownish colour) in the uppermost $20-30 \mathrm{~cm}$, is essential as recommended target $\mathrm{pH}$ values range from 6.0-6.9 depending on crop species and organic matter content. The lower $\mathrm{pH}$ further down the soil profile is a charactersitic feature of AS soils used for arable land, caused by oxidation of sulphides and low inherent carbonate concentrations (Palko 1994, Österholm 2005). There are significant vari- ations in the severity (e.g. pH and oxidation depth) between AS soils in different locations. Soils with high contents of sulphur that have only recently been drained (relatively little acidity has been leached) can in general be expected to be most severe, while for example high contents of organic matter may hamper the acidity (Österholm and Åström 2002). In the more severe Finnish AS soils $\mathrm{pH}$ drops below 3.5 (Yli-Halla et al. 1999, Österholm and Åström 2002). The $\mathrm{pH}$ of the AS soil profiles in this study (the upper meter), which are in the order F5 $<$ F3 $=\mathrm{F} 1<\mathrm{F} 4<\mathrm{F} 2$, are higher and can be considered moderate in terms of acidity.

The difference in the aqua-regia-extractable concentrations of $\mathrm{Co}, \mathrm{Ni}, \mathrm{Zn}, \mathrm{Mn}, \mathrm{Cu}$ and $\mathrm{Fe}$ was relatively small between the fields (not shown), while the S concentration differed significantly, with concentrations up to $7400 \mathrm{mg} \mathrm{kg}^{-1}$ in $\mathrm{F} 4$. The large $\mathrm{S}$ variation is explained by differences in inherent concentrations and extent of leaching. The element concentrations in the AS soils of this study are very similar to those of AS soils
Depth (cm)

F1

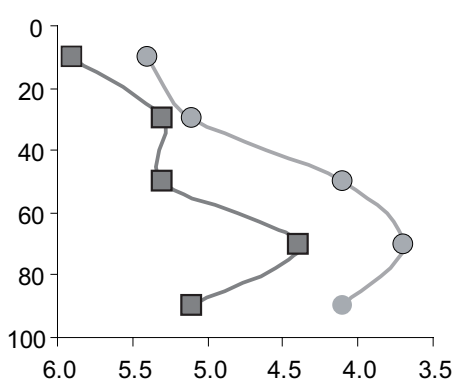

Depth $(\mathrm{cm})$

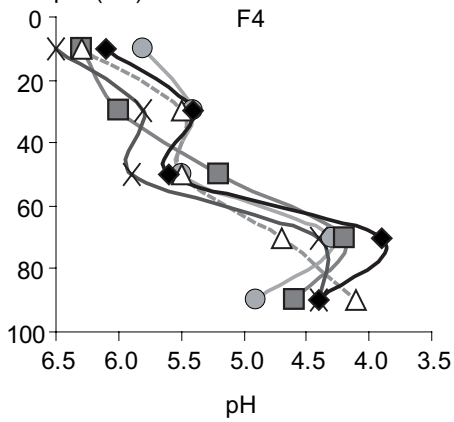

F2

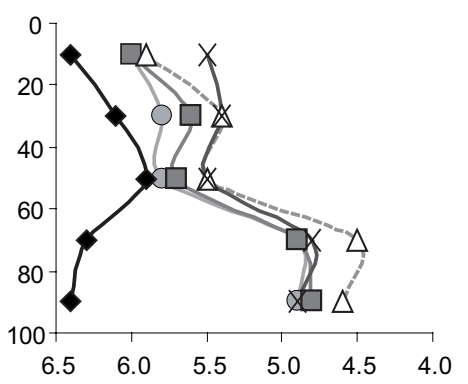

F5

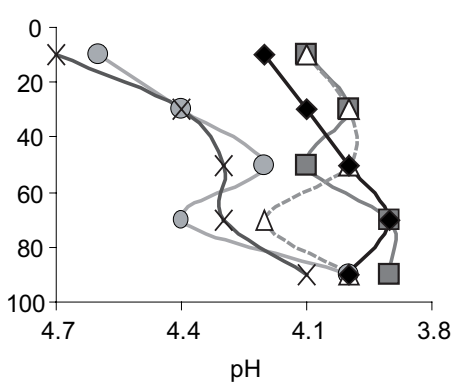

F3
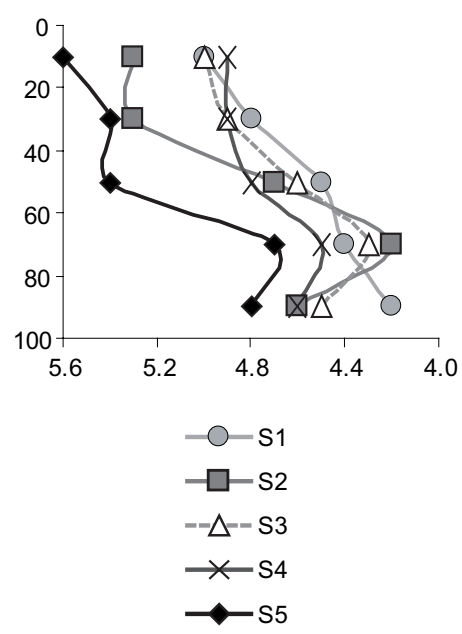

Fig. 2. Vertical $\mathrm{pH}$ variation in the soil profiles (S1-S5) in the studied fields (F1-F5). 
Fältmarsch, R. et al. Metal concentrations in oats grown on acid sulphate soils

elsewhere in the region, and are thus regionally representative (Österholm and Åström 2002, Nordmyr et al. 2006). It has been shown in several studies that the aqua-regia-extractable fraction of macro- and micronutrients in AS soils usually fall within the same range as reported for other types of soils (Österholm and Åström 2002, Sohlenius and Öborn 2004, Lax 2005).

The mean $\mathrm{NH}_{4} \mathrm{Ac}-\mathrm{EDTA}$-extractable concentrations of $\mathrm{Co}, \mathrm{Ni}, \mathrm{Zn}, \mathrm{Mn}$ and $\mathrm{Cu}$ in $\mathrm{F} 1-\mathrm{F} 5$ were relatively similar between the top- and subsoil, with the exception of $\mathrm{Fe}$, which was enriched in the subsoil (Table 1). The influence of the subsoil on the oats may have been relatively large due to the exceptionally dry growth season in 2006 .

\section{$\mathrm{Co}, \mathrm{Ni}, \mathrm{Zn}$ and $\mathrm{Mn}$}

The variation of the $\mathrm{NH}_{4}$ Ac-EDTA-extractable concentrations of $\mathrm{Co}, \mathrm{Ni}, \mathrm{Zn}$ and $\mathrm{Mn}$ in the soil profiles was much larger between-fields than withinfields (Table 1, Fig. 3). F3 was enriched in Co and $\mathrm{Ni}$, while F5, in which $\mathrm{pH}$ was lowest, showed the highest concentrations of $\mathrm{Zn}$ and Mn (Table 1). All these metals are chalcophilic and in the AS soils thus associated with sulphides (Öborn 1994). However, in comparison with the FAV, F1-F5 showed relatively similar values of $\mathrm{NH}_{4}$ Ac-EDTA-extractable $\mathrm{Co}, \mathrm{Ni}$ and $\mathrm{Zn}$ (except $\mathrm{Ni}$ in F3), and was even depleted in Mn (Table 1). This indicates that once released from sulphides, these four metals are not generally retained in the acidic soils but are flushed into drains. This is consistent with the abundance of these metals in streams draining AS soils (e.g. median concentrations of $110 \mu \mathrm{g} \mathrm{L}^{-1} \mathrm{Co}, 180 \mu \mathrm{g} \mathrm{L}^{-1}$ $\mathrm{Ni}, 5700 \mu \mathrm{g} \mathrm{L}^{-1} \mathrm{Mn}$ and $330 \mu \mathrm{g} \mathrm{L}^{-1} \mathrm{Zn}$ reported by Åström and Åström 1997, Österholm et al. 2005) and accumulation close to the ground-water table (Åström 1998, Österholm and Åström 2002).

The concentrations of $\mathrm{Co}, \mathrm{Ni}, \mathrm{Zn}$ and $\mathrm{Mn}$ in the oats were strongly correlated to those in both the top- and subsoil (Fig. 4). This indicate that the uptake of these four metals in oats grown on Finnish AS soils is not efficiently regulated by the plant but largely controlled by the concentrations of easily available fractions in the soil. However, with the exception of $\mathrm{Co}$ and $\mathrm{Ni}$ in F3, the concentrations of
$\mathrm{Co}, \mathrm{Ni}, \mathrm{Zn}$ and $\mathrm{Mn}$ were not in general elevated in the soils nor grains as compared to the FAV (Table 2, Fig. 4).

Yli-Halla and Palko (1987) found elevated soil ( $\mathrm{NH}_{4}$ Ac-EDTA-extractable) and oat grain concentrations of $\mathrm{Co}$ and $\mathrm{Ni}$, as compared to the $\mathrm{FAV}$, in AS soils located a few hundred $\mathrm{km}$ north of the present study sites. In a similar manner, the F3 site in this study showed corresponding anomalous values for $\mathrm{Co}$ and $\mathrm{Ni}$, both in the soil and grain (up to 4 times higher concentrations than for the FAV) (Table 2, Fig. 4). The primary sources of $\mathrm{Ni}$ in diet, which is the major exposure route in the general population, consist of meat, fish, grain and cereals (Adriano 2001). Although the potentially toxic Ni generally occurs at low concentrations in foods, enriched levels in oat grains, and possibly other crops, could be of concern for people with e.g. unbalanced diet habits, and livestock, relying abundantly on food sources originating from local soils. Therefore, an environmental risk assessment in AS soil environments would be pertinent and should include: (i) chemical composition of other food sources (e.g. vegetables, forage, cow-milk, fish) originating from AS soil landscapes, (ii) other potentially toxic chemical elements (e.g. Al, Cd, As) enriched in these products and (iii) connection between enriched concentrations of potentially toxic elements in farm produce and livestock and humans.

In F4, both the soil and oat concentrations of Co, Ni, Zn and Mn were low (Table 1, Fig. 4) while the aqua-regia-extractable $\mathrm{S}$ concentration in the soil was high. It is hypothesized that this field has yet to be significantly oxidised and leached, and thus has the potential for future metal release and subsequent extensive leaching to drains and, as shown in this study, possible uptake in oats.

\section{$\mathrm{Cu}$ and $\mathrm{Fe}$}

The $\mathrm{NH}_{4}$ Ac-EDTA-extractable concentration of $\mathrm{Cu}$ was stable downwards the profile in all fields, whereas the Fe concentration increased slightly downwards in several profiles (Fig. 3). Overall, the concentration of $\mathrm{Fe}$ and $\mathrm{Cu}$ in $\mathrm{F} 1-\mathrm{F} 5$ were lower than the FAV (Table 1). The Fe concentration and 
Vol. 18 (2009): 45-56.

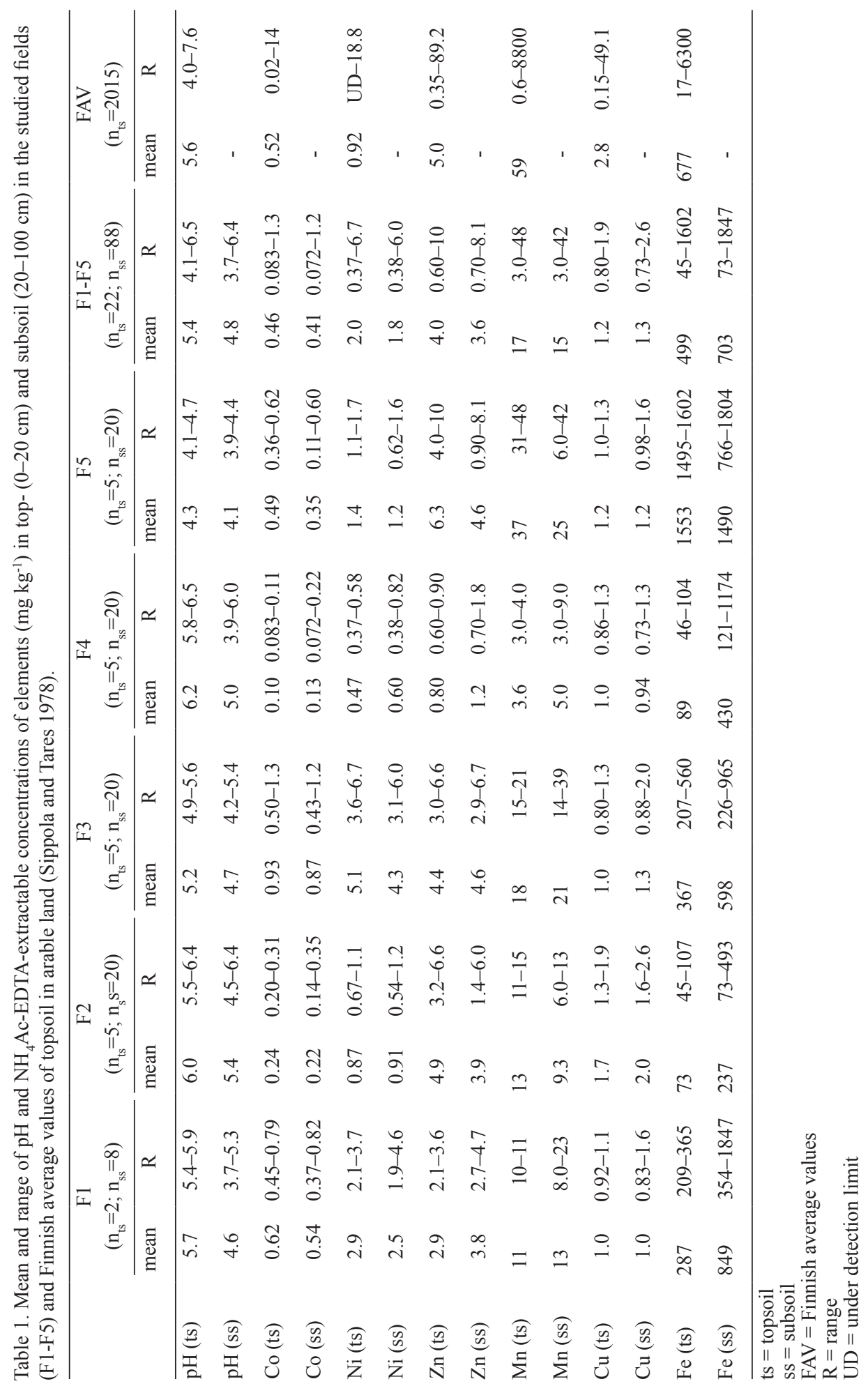


Fältmarsch, R. et al. Metal concentrations in oats grown on acid sulphate soils
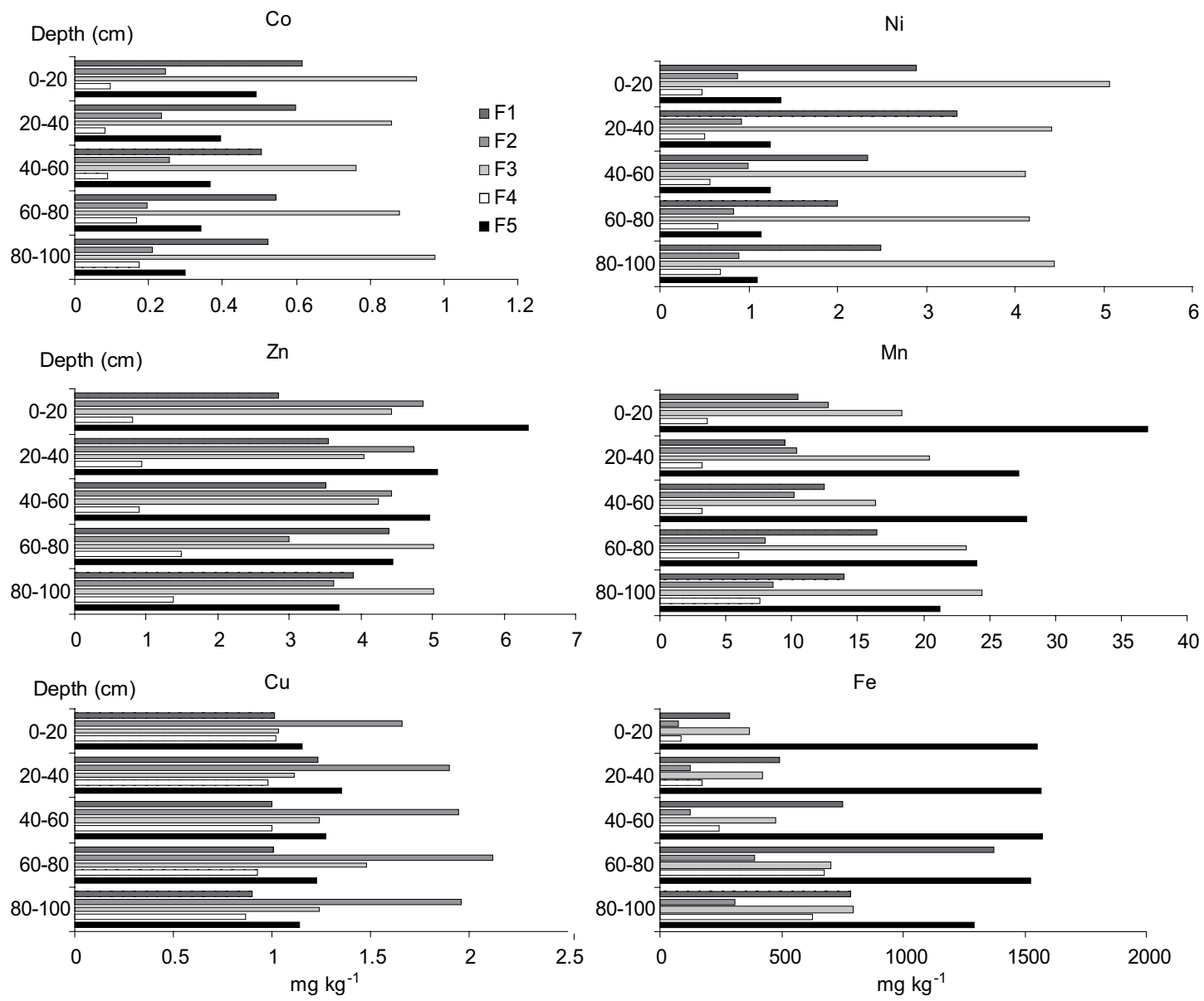

Fig. 3. Mean $\mathrm{NH}_{4} \mathrm{Ac}-\mathrm{EDTA}$-extractable concentrations $\left(\mathrm{mg} \mathrm{kg}^{-1}\right)$ of elements in the soil profiles.

Table 2. Mean oat grain concentrations of elements in the studied fields (F1-F5) and corresponding Finnish average values (Varo et al. 1980).

\begin{tabular}{lccccccc}
\hline & $\begin{array}{c}\mathrm{F} 1 \\
(\mathrm{n}=6)\end{array}$ & $\begin{array}{c}\mathrm{F} 2 \\
(\mathrm{n}=5)\end{array}$ & $\begin{array}{c}\mathrm{F} 3 \\
(\mathrm{n}=5)\end{array}$ & $\begin{array}{c}\mathrm{F} 4 \\
(\mathrm{n}=5)\end{array}$ & $\begin{array}{c}\mathrm{F} 5 \\
(\mathrm{n}=5)\end{array}$ & $\begin{array}{c}\mathrm{F} 1-\mathrm{F} 5 \\
(\mathrm{n}=26)\end{array}$ & $\begin{array}{c}\mathrm{FAV} \\
(\mathrm{n}=36)\end{array}$ \\
\hline $\mathrm{Co}\left(\mathrm{\mu g} \mathrm{kg}^{-1}\right)$ & 70 & 16 & 228 & 48 & 68 & 86 & $81^{*}$ \\
$\mathrm{Ni}\left(\mathrm{mg} \mathrm{kg}^{-1}\right)$ & 3.6 & 1.6 & 11 & 2.1 & 4.0 & 4.5 & $2.8^{*}$ \\
$\mathrm{Zn}\left(\mathrm{mg} \mathrm{kg}^{-1}\right)$ & 65 & 54 & 63 & 39 & 66 & 57 & $43^{*}$ \\
$\mathrm{Mn}\left(\mathrm{mg} \mathrm{kg}^{-1}\right)$ & 40 & 38 & 60 & 37 & 63 & 48 & $72^{*}$ \\
$\mathrm{Cu}\left(\mathrm{mg} \mathrm{kg}^{-1}\right)$ & 6.9 & 6.5 & 7.2 & 6.5 & 7.4 & 6.9 & $5.6^{*}$ \\
$\mathrm{Fe}\left(\mathrm{g} \mathrm{kg}^{-1}\right)$ & 63 & 74 & 64 & 92 & 92 & 77 & $60^{*}$ \\
\hline
\end{tabular}

FAV $=$ Finnish average values

${ }^{*}$ Converted to dry weight. 
Vol. 18 (2009): 45-56.
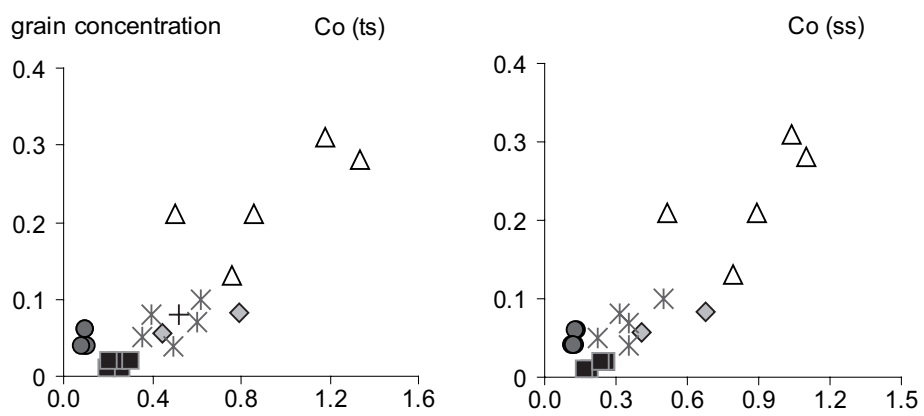

$\mathrm{Ni}$ (ts)

grain concentration $\mathrm{Ni}(\mathrm{ss})$

$\mathrm{Zn}(\mathrm{ts})$
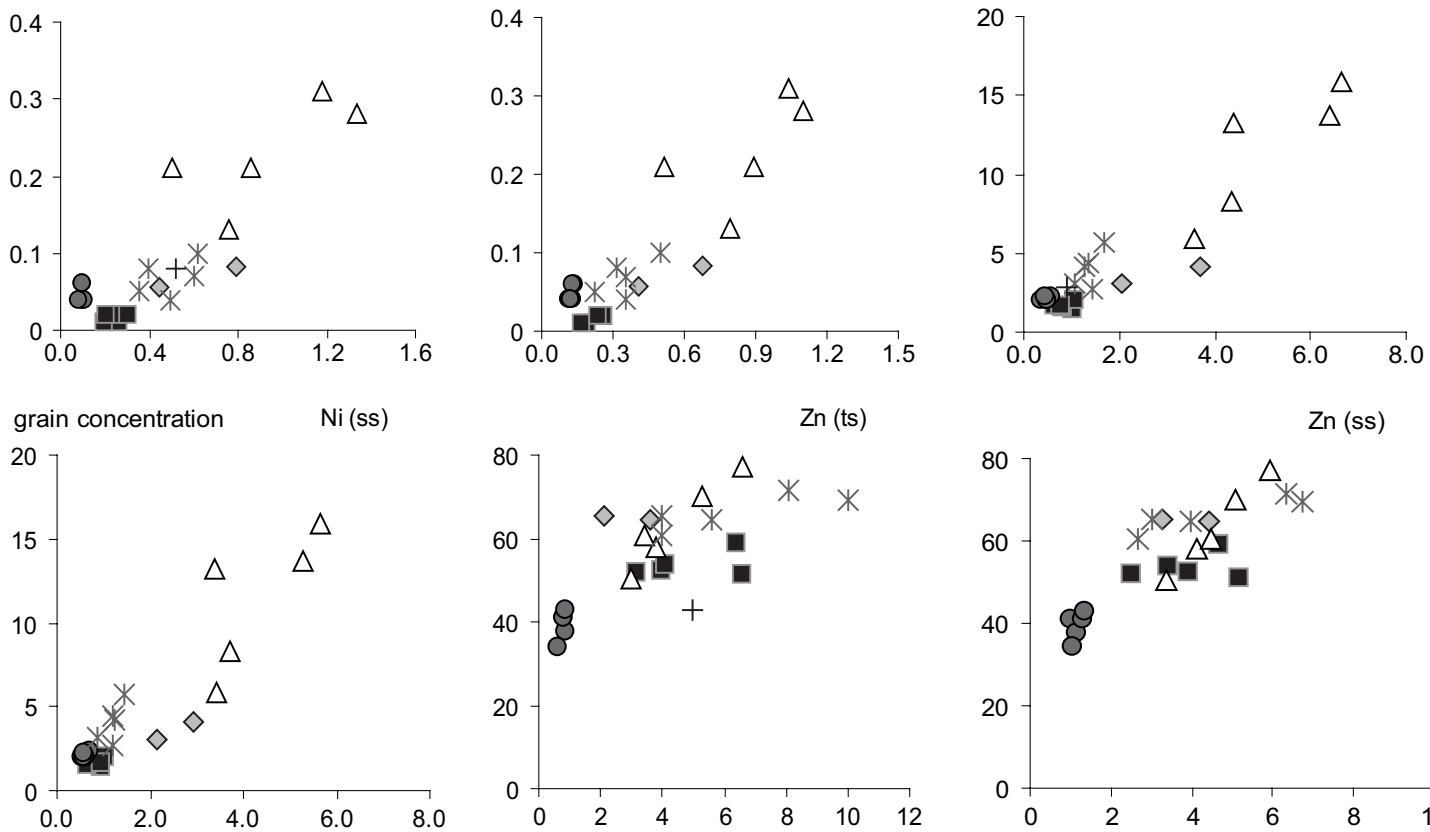

grain concentration

$\mathrm{Mn}(\mathrm{ts})$

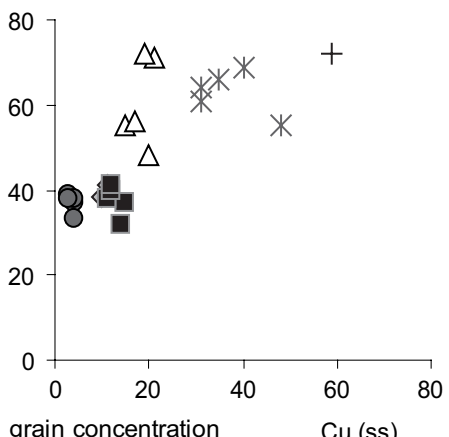

Mn (ss)

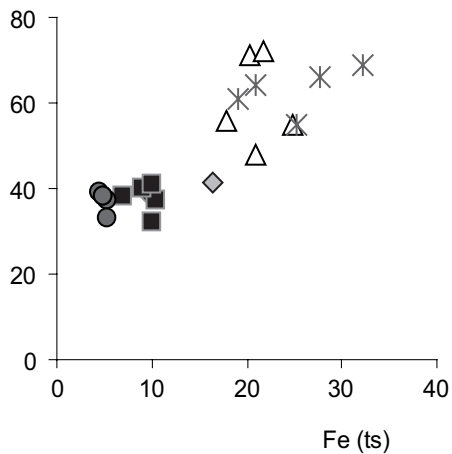

$\mathrm{Cu}$ (ts)
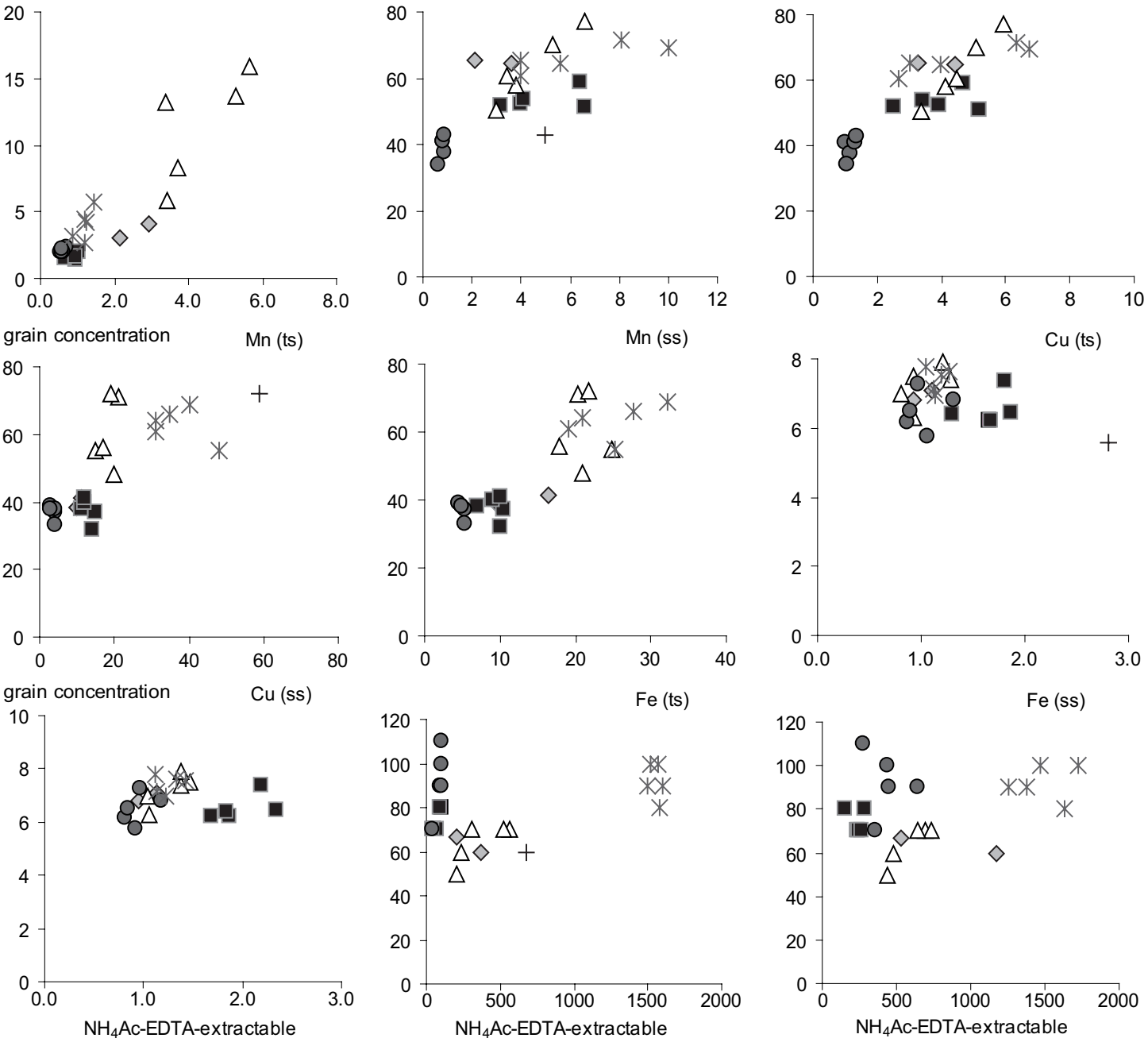

$$
\diamond \mathrm{F} 1 \quad \square \mathrm{F} 2 \quad \triangle \mathrm{F} 3 \quad \text { OF4 } \quad \text { WF5 } \quad \text { +FAV }
$$

Fig. 4. Mean $\mathrm{NH}_{4}$ Ac-EDTA-extractable concentrations $\left(\mathrm{mg} \mathrm{kg}^{-1}\right)$ of elements in top- (ts, $\left.0-20 \mathrm{~cm}\right)$ and subsoil (ss, $20-$ $100 \mathrm{~cm}$ ) versus oat. The FAV of $\mathrm{NH}_{4}$ Ac-EDTA-extractable elements in topsoil and oat is also indicated (Sippola and Tares 1978, Varo et al. 1980). 
Fältmarsch, R. et al. Metal concentrations in oats grown on acid sulphate soils

pH were inversely correlated (Fig. 5), indicating that the abundance of the $\mathrm{NH}_{4} \mathrm{Ac}$-EDTA-extractable $\mathrm{Fe}$ fraction is controlled by soil acidity. It is, however, notable that although $\mathrm{Fe}$ is mobilised within the AS soil, it is only leached to a limited extent since it is abundantly reprecipitated on surfaces of oxic soil aggregates and cracks as amorphous oxide ( $\mathrm{Fe}$ oxyhydroxides) coatings (Österholm and Åström 2002) to which $\mathrm{Cu}$ also is readily absorbed (KabataPendias 2001). It has been suggested that plant roots are able to reduce $\mathrm{Fe}^{3+}$ to $\mathrm{Fe}^{2+}$ which is more readily absorbed by plants (Christ 1974, Kabata-Pendias 2001). Additionally, plant roots of grass plants are capable of releasing $\mathrm{Fe}$ and $\mathrm{Cu}$ via the secretion of phytosiderophores, which enhance metal solubility through chelation (Shenker et al. 2001). The extraction of $\mathrm{Cu}$ and $\mathrm{Fe}$ with $\mathrm{NH}_{4}$ Ac-EDTA may therefore underestimate the easily available fraction due to the inability to dissolve the Fe(III) phases. Although $\mathrm{Fe}$ and $\mathrm{Cu}$ were not abundantly released by $\mathrm{NH}_{4} \mathrm{Ac}$-EDTA (except $\mathrm{Fe}$ in F5), they were somewhat elevated in the oats as compared to the FAV (Table 2, Fig. 4). This pattern is consistent with the above mentioned suggestion that $\mathrm{NH}_{4} \mathrm{Ac}$-EDTA is not an efficient extractant of $\mathrm{Fe}$ and $\mathrm{Cu}$ in these soils, and that oxides, which are abundant in AS soils, are a significant carrier of these metals from which they are available for plant uptake.

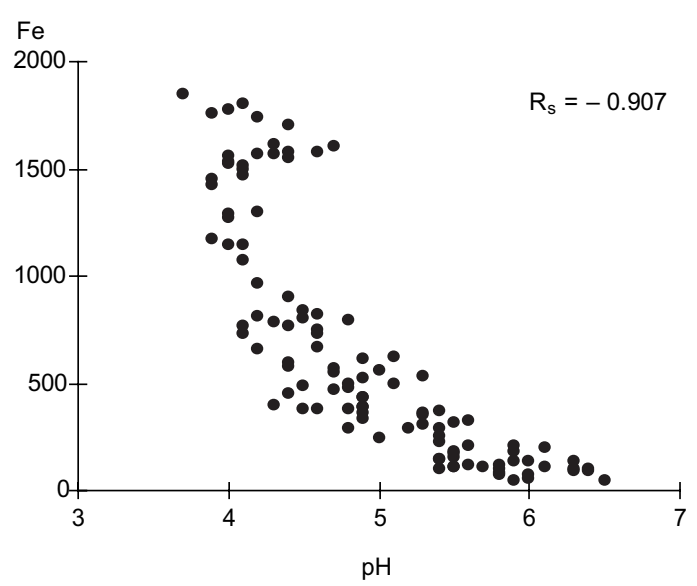

Fig. 5. The $\mathrm{NH}_{4}$ Ac-EDTA-extractable Fe concentration $\left(\mathrm{mg} \mathrm{kg}^{-1}\right)$ versus soil $\mathrm{pH}(\mathrm{n}=110)$.

\section{Conclusions}

The concentrations of $\mathrm{Co}, \mathrm{Ni}, \mathrm{Mn}$ and $\mathrm{Zn}$ in the oats were correlated with corresponding concentrations extracted from the soil by $\mathrm{NH}_{4}$ Ac-EDTA. This indicates that geochemistry is an important control of the abundance of these metals in oats grown on typical Finnish AS soils. However, while these chalcophilic metals are abundantly released in the AS soils, a large portion is in general leached into drains, and not retained in the soil as an easily extractable pool. Therefore, these metals were not in general elevated in the oats. On one field however, $\mathrm{Co}$ and Ni were significantly elevated in the soil, and thus also in the oats. An environmental risk assessment would be motivated to elucidate if $\mathrm{Ni}$ concentrations are enriched in livestock and humans in these landscapes. The $\mathrm{NH}_{4}$ Ac-EDTA-extractable concentrations of $\mathrm{Cu}$ and $\mathrm{Fe}$ in the soils could not explain the concentrations of these metals in the oats, and it was therefore argued that biological processes (e.g. plant-root chemistry) overshadow geochemical heterogeneity.

Acknowledgements. The study was financially supported by Svenska litteratursällskapet i Finland r.f. (Ingrid, Margit och Henrik Höijers Donationsfond II), Renlunds Stiftelse, Oskar Öflunds Stiftelse, Waldemar von Frenckells Stiftelse and the Åbo Akademi Foundation. We thank Markku Kontturi and Arto Timonen at the Agrifood Research Laboratory in Jokioinen for their help and assistance with the pretreatment of the oat samples. Merja Eurola at Agrifood Research Finland is acknowledged for providing information and data conserning oats. Christer Öist and Anders Grannas are recognized for their information regarding the studied fields.

\section{References}

Adriano, D. C. 2001. Trace elements in terrestrial environments. 2nd ed. Springer-Verlag, New York. 867 p.

Andriesse, W. \& van Mensvoort, M.E.F. 2002. Distribution and extent of acid sulphate soils. In: Lal, R. (ed.) Encyclopedia of Soil Science, Marcel Dekker Inc., New York. p. 1-6.

Åström, M. 1998. Partitioning of transition metals in oxidised and reduced zones of sulphide-bearing fine-grained sed- 
Vol. 18 (2009): 45-56.

iments. Applied Geochemistry 13: 607-617.

Åström, M. \& Åström, J. 1997. Geochemistry of stream water in a catchment in Finland affected by sulphidic fine sediments. Applied Geochemistry 12: 593-605.

Atlas of Finland 1987. Atlas of Finland. Climate (folio 131), 131. National Board of Survey Geographical Society of Finland.

Bärlund, I., Tattari, S., Yli-Halla, M. \& Åström, M. 2004. Effects of sophisticated drainage techniques on groundwater level and drainage water quality on acid sulphate soils - Final report of the HAPSU project. The Finnish Environment 732. $68 \mathrm{p}$.

Callinan, R.B., Fraser, G.C. \& Melville, M.D. 1993. Seasonally recurrent fish mortalities and ulcerative disease outbreaks associated with acid sulfate soils in Australian estuaries. In: Dent, D.L., van Mensvoort, M.E.F. (eds.) Selected Papers of the Ho Chi Minh City Symposium on Acid Sulfate Soils, ILRI Pub. No. 53, Wagening. p. 403-410.

Christ, R.A. 1974. Iron requirement and iron uptake from various iron compounds by different plant species. Plant Physiology 54: 582-585.

Dent, D.L. \& Pons, L.J. 1995. A world perspective on acid sulphate soils. Geoderma 67: 263-276.

Erviö, R. \& Palko, J. 1984. Macronutrient and micronutrient status of cultivated acid sulphate soils at Tupos, Finland. Annales Agriculturae Fenniae 23: 121-134.

Fältmarsch, R., Åström, M.E. \& Vuori, K.M. 2008. Environmental risks of metals mobilised from acid sulphate soils in Finland: a literature review. Boreal Environment Research 13: 444-456.

Gill, R. 1997. Modern analytical geochemistry. An introduction to quantitative chemical analysis techniques for earth, environmental and materials scientists. Longman, Harlow. 329 p.

Golez, N.V. \& Kyuma, K. 1997. Influence of pyrite oxidation and soil acidification on some essential nutrient elements. Aquacultural Engineering 16: 107-124.

Hildén, M., Hudd, R. \& Lehtonen, H. 1982. The effects of environmental changes on the fisheries and fish stocks in the Archipelago sea and the Finnish part of the Gulf of Bothnia. Aqua Fennica 12: 47-58.

Hudd, R., Hildén, M., Urho, L., Axell, M.-B. \& Jåfs, L.A. 1984. Fishery investigations (in 1980-1982) of the Kyrönjoki River estuary and its influence area in the northern Quark of the Baltic Sea. National Board of Waters, Report 242B. [In Finnish and Swedish with English summary].

Joukainen, S. \& Yli-Halla, M. 2003. Environmental impacts and acid loads from deep sulfidic layers of two welldrained acid sulfate soils in western Finland. Agriculture, Ecosystems and Environment 95: 297-309.

Kabata-Pendias, A. 2001. Trace elements in soils and plants. 3rd ed. CRC Press, Boca Raton. 413 p.

Korsman, K., Koistinen, T., Kohonen, J. et al. (eds.) 1997. Bedrock Map of Finland 1: 1000 000. Geological Survey of Finland, Espoo, Finland.

Lakanen, E. \& Erviö, R. 1971. A comparison of eight extractants for the determination of plant available micronutrients in soils. Acta Agralia Fennica 123: 223-232.

Lax, K. 2005. Stream plant chemistry as indicator of acid sulphate soils in Sweden. Agricultural and Food Science 14: 83-97.
Meriläinen, J.J. 1989. Impact of an acid, polyhumic river on estuarine zoobenthos and vegetation in the Baltic Sea, Finland. Ph.D. thesis, University of Jyväskylä, Finland. $48 \mathrm{p}$.

Nordmyr, L., Boman, A., Åström, M. \& Österholm, P. 2006. Estimation of leakage of chemical elements from boreal acid sulphate soils. Boreal Environment Research 11: $261-273$.

Öborn, I. 1994. Morphology, chemistry, mineralogy and fertility of some acid sulfate soils in Sweden. Ph.D. thesis, University of Uppsala, Sweden. 65 p.

Österholm, P. 2005. Previous, current and future leaching of sulphur and metals from acid sulphate soils in W. Finland. Ph.D. thesis, Åbo Akademi University, Finland. $35 \mathrm{p}$.

Österholm, P. \& Åström, M. 2002. Spatial trends and losses of major and trace elements in agricultural acid sulphate soils distributed in the artificially drained Rintala area, W. Finland. Applied Geochemistry 17: 1209-1218.

Österholm, P., Åström, M. \& Sundström, R. 2005. Assessment of aquatic pollution, remedial measures and juridical obligations of an acid sulphate soil area in western Finland. Agricultural and Food Science 14: 44-56.

Palko, J. 1994. Acid sulphate soils and their agricultural and environmental problems in Finland. Ph.D. thesis, University of Oulu, Finland. 58 p.

Palko, J. \& Yli-Halla, M. 1988. Solubility of Co, Ni and Mn in some extractants in a Finnish acid sulphate soil area. Acta Agriculturae Scandinavica 38: 153-158.

Palko, J. \& Yli-Halla, M. 1990. Solubility of Al, Cr, Cu and $\mathrm{Zn}$ in soils from a Finnish acid sulphate soil area. Acta Agriculturae Scandinavica 40: 117-122.

Puustinen, M., Merilä, E., Palko, J. \& Seuna, P. 1994. Drainage level, cultivation practises and factors affecting load on waterways in Finnish farmland. National Board of Waters and Environment, Research Report A198. [In Finnish with English summary].

Räisänen, M.L., Tenhola, M. \& Mäkinen, J. 1992. Relationship between mineralogy and the physico-chemical properties of till in central Finland. The Bulletin of the Geological Society in Finland 64: 35-58.

Ritsemaa, C.J., van Mensvoort, M.E.F., Dent D.L., Tan Y., van den Bosch H. \& van Wijk, A.L.M. 2000. In: Sumner, M.E. (ed.) Handbook of Soil Science, CRC Press, Boca Raton. p. 121-154.

Saari, E. \& Paaso, A. 1980. Mineral element composition of Finnish Foods. Acta Agriculturae Scandinavica Supplementum 22: 15-25.

Shenker, M., Fan, T. W.-M. \& Crowley, D.E. 2001. Phytosiderophores influence on cadmium mobilization and uptake by wheat and barley plants. Journal of Environmental Quality 30: 2091-2098.

Sippola, J. \& Tares, T. 1978. The soluble content of mineral elements in cultivated Finnish soils. Acta Agriculturae Scandinavica Supplementum 20: 11-25.

Sohlenius, G. \& Öborn, I. 2004. Geochemistry and partitioning of trace metals in acid sulphate soils in Sweden and Finland before and after sulphide oxidation. Geoderma 122: 167-175.

Varo, P., Nuurtamo, M., Saari, E. \& Koivistoinen, P. 1980. Mineral element composition of Finnish foods. III. Annual variations in the mineral element composition of cereal grains. Acta Agriculturae Scandinavica Supple- 
Fältmarsch, R. et al. Metal concentrations in oats grown on acid sulphate soils

mentum 22: 27-35.

Vuori, K.-M. 1996. Acid-induced acute toxicity of aluminium to three species of filter feeding caddis larvae (Trichoptera, Arctopsychidae and Hydropsychidae). Freshwater Biology 35: 179-188.

Wiklander, L. \& Hallgren, G. 1949. Studies on gyttja soils: I. Distribution of different sulfur and phosphorus forms and of iron, manganese and calcium carbonate in a profile from Kungsängen. The Annals of the Royal Agricul- tural College of Sweden 16: 811-827.

Yli-Halla, M. \& Palko, J. 1987. Mineral element content of oats (Avena sativa L.) in an acid sulphate soil area of Tupos village, northern Finland. Journal of Agricultural Science in Finland 59: 73-78.

Yli-Halla, M., Puustinen, M. \& Koskiaho, J. 1999. Area of cultivated acid sulfate soils in Finland. Soil Use and Management 15: 62-67. 